\title{
The Influence of Perceived Over Qualification on College Students' Classroom
}

\section{Learning}

\section{HuiXU}

Center for Industrial Policy and Management Research, Wuhan University of Science and Technology, No.947, Heping Avenue, Qingshan District, Wuhan, China E-mail:694996720@qq.com

\section{Pan HUANG}

Center for Industrial Policy and Management Research,

Wuhan University of Science and Technology,

No.947, Heping Avenue, Qingshan District, Wuhan, China E-mail:1401393818@qq.com

\author{
Yun-Mei LI \\ Center for Industrial Policy and Management Research, \\ Wuhan University of Science and Technology, \\ No.947, Heping Avenue, Qingshan District, Wuhan, \\ China \\ E-mail: lymwust@163.com
}

\section{Keywords-Perceived OverQualification; Learning Interest;Learning Input Degree; Knowledge Sharing; Teaching Management;}

\section{INTRODUCTION}

Perceived overqualification from the literal speaking is the individual perceived their own qualifications higher than the actual learning or job requirements arising from a psychological phenomenon. In terms of domestic higher education, due to the increasing emphasis on education, the number of college students in China is increasing year by year. In these college students, there are some of the original qualification is too high, but for various reasons lead to the college entrance examination defeat, and then with their dream of famous university missed, so as to enter the unsatisfactory university. For ordinary colleges, recruiting too high quality students is a double-edged sword, improve the quality of students, but sometimes to the teaching work to bring trouble, high-quality students in the university classroom may exist learning negative neglect, learning status is poor, not satisfied with the 
teaching and other issues, leading to academic performance and other aspects of the requirements of college teaching objectives.

Western researchers have studied many issues such as perceived overqualification of work, attitudes, performances and behavior patterns of employees. However, there are few studies on the perception of excessive qualifications in China, especially in the field of education. The research on the effect of classroom learning is rare among college students. However, classroom learning is the main form of College Students' learning, and occupies an important position in college students' daily time, which greatly affects the learning effect of College students. Therefore, the in-depth study and analysis of the effect of College Students' classroom learning can not only broaden the scope of research, but also provide reference for future related research. And this research can give students some effective suggestions to improve their classroom learning, saving extra-curricular learning time, to achieve a multiplier effect. It also brings constructive inspiration to the educational administrators in Colleges to help them achieve their teaching goals that can meet the needs of social development.

\section{RESEARCH HYPOTHESIS AND THEORETICAL MODEL}

\section{A. Perceived Over Qualification and Learning Interest}

Since 1970, the phenomenon of Excessive aptitude in western academia, summed up the content includes three aspects: perceived overqualified and demographic; perceived overqualified and individual and occupation; perceived overqualified and work attitudes, behavior and performance[1].

In 1996, Freeman put forward the concept of "over education" from the angle of educational economics [2]. In western countries, there have been 20 years of perceived over qualification research. At present, there is no clear definition and concept about the perception of excessive aptitudein academic circles. Johnson adhere to the perceived over qualification is a kind of individual and task matching degree or work matching the difference in point of view, it shows that the post does not match, education, insufficient use of excess skills and lack of opportunities for the development[3]. Maynard defines excessive perception as an excess of perceived as training, experience,knowledge, skills, and abilities[4].

Learning interest from the perspective of educational psychology, is a person tend to study the psychological characteristics of a certain knowledge[5], which is a tendency to explore the unknown world. College students are the main body of classroom learning, therefore, the effect of College Students' classroom learning depends largely on whether students have interest in learning. When students have the interest in learning, he will go to think actively, to realize the joy of learning.If the students do not learn enthusiasm, it will not achieve the desired learning effect. However, according to the relevant literature, we can see that the self-learning ability of self-learning is higher than that of classroom teaching, so their interest in learning is not as strong as that of ordinary individuals.

\section{B. Perceived OverQualification and Learning Input}

\section{Degree}

Recently, with the rapid development of education, the investigation of College Students' classroom learning has become a new direction for managers of higher education. Alexander, George and other scholars argue that learning input is the same as learning participation, that is, the degree to which students engage in thought and behavior in their learning activities. On learning input degree, Jennifer Fredrick and other scholars through a lot of investigation and research data, analysis of the literature on learning commitment: the definition of learning input degree with the behavior, emotional and cognitive three aspects of the concept [6]. In combination with foreign studies, we find that learning input degree includes two important aspects: the emotion that students invest in learning and the students' recognition of their own learning environment. Therefore, the perceived over qualification college students' engagement in classroom learning is lower than that of effective learning time and energy.

\section{Perceived OverQualification and Knowledge Sharing}

In the study of knowledge sharing behavior, scholars define it differently. Dixon thinks that knowledge sharing behavior is a process that individuals share knowledge diffusion by individual groups, to form a network, like a 
Domino effect, which can quickly improve the efficiency of the organization [7]. Srivastava and Bartol's point of knowledge sharing is the individual will have its own knowledge, through the appropriate way to selectively to make these knowledge to reproduce the original or new form of [8]. And the knowledge sharing behavior has two processes: sharing knowledge and digesting knowledge.

The main purpose of high school and junior high school is to master the theoretical knowledge, but the purpose of learning at the university stage is to cultivate the way of thinking and learning skills[9]. Therefore, individuals are often faced with the inability to achieve their goals alone. Individuals share knowledge with each other, forming a network, such as domino effect, can quickly improve the efficiency of learning. For the knowledge owner that is the economic benefit obtained, for the knowledge recipient that is to obtain the appropriate ability to improve their own value and so on, resulting the power of the exchange and sharing knowledge[10]. It can be seen that the individual's high qualification makes it more willing to share his knowledge with others.Through the above preliminary discussion, we can present the following research hypothesis:

H1: The influence of perceived overqualification on College Students' learning interest in classroom is negative;

$\mathrm{H} 2$ : The influence of perceived overqualification on College Students' learning degree of input in classroom is negative;

H3: The influence of perceived overqualification on knowledge sharing behavior of college students is positive.

The purpose of this study is to use hypothesis testing the assume that perceived overqualification negatively influences college students' learning interest in classroom and their learning input degree, which positively influences college students' knowledge sharing behavior. Then we use the data analysis to prove the hypothesis, and the theoretical model is shown in figure 1 :

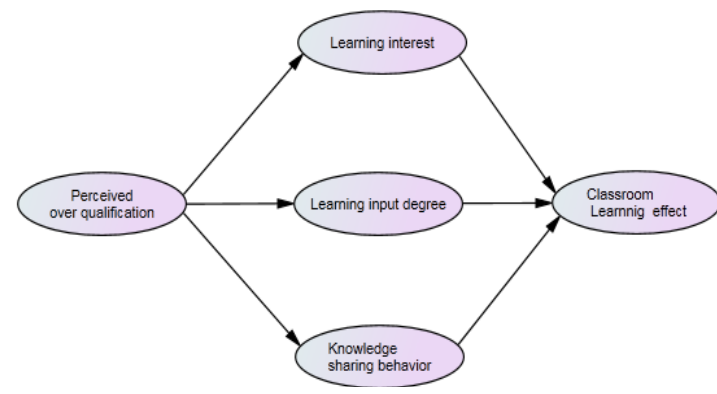

Figure1 theoretical model

\section{DATA ANALYSIS}

\section{A. Data Collection}

The main purpose of this study is to investigate the influence of perceived overqualification on learning interest, learning input degree and knowledge sharing behavior. Questionnaire using the Likert five point scale, was distributed on the professionalwebsite, and finally recover 227 valid questionnaires with high qualification. In the survey, the college or higher accounted for $85.8 \%$ of the total sample, therefore, the sampling object is valid.

\section{B. Reliability and validity test of scale}

The reliability and validity of the internal consistency of the questionnaire were analyzed by the $\alpha$-reliability coefficient method, the KMO value and the Barter spherical test in SPSS 22.0 statistical analysis software. The results are shown in Table 1:

TABLE 1 RELIABILITY ANALYSIS

\begin{tabular}{ccccc}
\hline Variable & Learning & Learning & Knowledge & All \\
& interest & input & sharing & \\
& & degree & behavior & \\
\hline Item & 6 & 5 & 5 & 16 \\
Cronbach's $\alpha$ & 0.754 & 0.728 & 0.710 & 0.762 \\
\hline
\end{tabular}

The overall $\alpha>0.7$ of the questionnaire, so the results are ideal, indicating that the consistency of all projects is better, also shows that the questionnaire has a good reliability. The validity of the samples was tested by KMO and Bartlett spherical test. That the KMO was 0.796( $>0.7)$, indicating that there is no significant difference in the degree of correlation between the variables. The results of the Bartlett's Sphere test: Sig $=0.000<0.05$, then the 
spherical hypothesis is rejected, so the variables are not independent.

\section{Descriptive statistics and related analysis}

The correlation coefficient matrix was obtained by SPSS 22.0 correlation analysis, as shown in Table 2.

TABLE 2 CORRELATION COEFFICIENT MATRIX OF VARIABLES

\begin{tabular}{lcccccc}
\hline & M & SD & 1 & 2 & 3 & 4 \\
\hline Perceived & 3.71 & 0.682 & 1 & & \\
overqualification & 3 & & & & \\
\hline Learning interest & 3.36 & 0.853 & $-0.551^{* *}$ & 1 & \\
\hline Learning input & 3.90 & 0.650 & $-0.313^{* *}$ & 0.221 & 1 \\
& 0 & & & & \\
\hline Knowledge & 3.78 & 0.591 & $0.443^{* *}$ & $0.313^{*}$ & $0.221^{*}$ \\
sharing & 1 & & & & \\
\hline
\end{tabular}

The data in the table show that the perceived overqualification is negatively related to the learning interest and learning input degree. Perceived overqualification is positively related to students' knowledge sharing behavior. Three hypotheses have been preliminarily validated. In order to further analyze the impact of the two variables, this paper uses multiple regression analysis to further analyze the variables' concerns. In order to see the regression coefficients and significance of each regression equation more intuitively, we divide the regression equation into 3 parts. The results are shown in table 3.
TABLE 3. MULTIVARIATE REgRESSION ANALYSIS

\begin{tabular}{|c|c|c|c|c|c|}
\hline $\begin{array}{c}\text { Independent } \\
\text { variable }\end{array}$ & $\begin{array}{l}\text { Dependent } \\
\text { variable }\end{array}$ & $\begin{array}{c}\text { Bet } \\
\text { a }\end{array}$ & $\mathrm{t}$ & $\mathrm{R}^{2}$ & $\mathrm{~F}$ \\
\hline $\begin{array}{c}\text { Perceived } \\
\text { overqualification }\end{array}$ & $\begin{array}{l}\text { Learning } \\
\text { interest }\end{array}$ & $\begin{array}{r}-0.2 \\
21\end{array}$ & $\begin{array}{c}-3.314^{* *} \\
*\end{array}$ & $\begin{array}{c}0.04 \\
6\end{array}$ & 7.956 *** \\
\hline $\begin{array}{c}\text { Perceived } \\
\text { overqualification }\end{array}$ & $\begin{array}{c}\text { Learning } \\
\text { input }\end{array}$ & $\begin{array}{l}-0.3 \\
67\end{array}$ & $\begin{array}{c}-6.074^{* *} \\
*\end{array}$ & $\begin{array}{c}0.20 \\
4\end{array}$ & $\begin{array}{c}41.168 * * \\
*\end{array}$ \\
\hline $\begin{array}{c}\text { Perceived } \\
\text { overqualification }\end{array}$ & $\begin{array}{l}\text { Knowledge } \\
\text { sharing } \\
\text { behavior }\end{array}$ & $\begin{array}{l}0.2 \\
74\end{array}$ & $4.256^{* * *}$ & $\begin{array}{c}0.08 \\
5\end{array}$ & $\begin{array}{c}17.490 * * \\
*\end{array}$ \\
\hline
\end{tabular}

Through the above analysis we can see that the three regression equations have passed the significance test. Perceived overqualification has a significant effect on knowledge sharingbehaviour. The effect of perceived overqualificationon learning interest and learning input is negative. The effect of perceived overqualification on the knowledge sharing behavior of college students in classroom learning is positive.

In summary, the perceived overqualification has a different degree of influence on the learning interest, learning input and knowledge sharing behavior of college students in class learning. Therefore, it can be concluded that the influence of perceived overqualification on college students' classroom learning effect is positive and negative. The theoretical model established in this paper has been verified. As shown in Figure 2

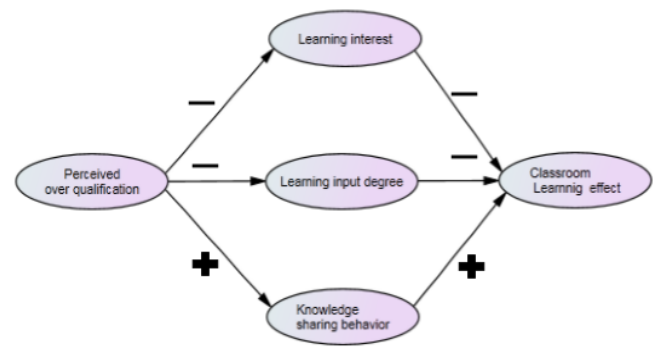

Figure 2 Conclusion

\section{RESEARCH CONCLUSION AND ENLIGHTENMENT}

\section{A. Research Conclusion}

On the basis of the research hypothesis, through the model verification analysis, the influence ofperceived 
overqualification on the learning interest, learning input and knowledge sharing behavior of college students' classroom learning draws the following conclusions:

(1) The influence of perceived overqualification on College Students' interest in classroom learning is negative. That is, the higher perceived overqualification, the lower the interest in learning. The perceived overqualified students are prone to mental weariness, not interested in teaching content, sitting in the corner of the class, do not want to listen, learning in a passive state, to answer questions are not active, resulting in classroom teaching to become invalid teaching.

(2) The effect of perceived overqualification on college students' classroom input is also negative. That is, the higher the ability to the perceived overqualification, the lower the degree of learning input. Perceived overqualification of college students love to play the phone, do not listen carefully, self-righteous casually listen to the teacher's teaching content disapproval.

(3) The effect of perceived overqualification on knowledge sharing behavior of college students is positive. That is, the higher the perceived over qualification, the more active the students share knowledge. Qualified college students are willing to help other students, like to participate in academic exchanges, for other students have an open exchange of mind, which is conducive to the formation of a good classroom learning atmosphere.

In conclusion, we cannot be one-sided view of the perceived over qualification to college students to learn the impact, but to dialectical attitude to look at it.Our research on the perceived over qualification cannot be too one-sided, it is necessary to analyze its negative side, but also to analyze its merits.

\section{B. Enlightenment}

This paper studies the three aspects of learning interest, learning input and knowledge sharing behavior in college students 'classroom learning, and it is both beneficial and effective to get the effect of high qualification on college students' classroom learning. Therefore, based on the above analysis, the following recommendations are made:

a) How can teachers improve the effect of classroom teaching?

(1) It is a key factor for teachers to make appropriate teaching methods in classroom teaching. For students of different qualifications, teachers should not only achieve the unity of teaching content, but also teach students in accordance with their aptitude. Therefore, the appropriate teaching methods are conducive to improving the effect of classroom learning, but also help teachers to achieve their desired teaching goals.

(2) In classroom teaching, teachers should pay attention to listening to students' teaching opinions, and create a good and equal atmosphere for students to improve the effect of classroom teaching. In addition, the teacher should pay attention to the classroom communication between students and students, guide students to take the initiative to the perceived overqualified and ordinary students exchange learning experience, learn from each other, in order to improve the effect of classroom teaching in university.

b) How do college students with high aptitude perceive themselves to improve their classroom learning?

The teaching process is two-way, and to achieve a certain teaching effect, we cannot just ask the education managers how to change, but also from the perspective of students to improve. Therefore, college students who have high aptitude should also provide corresponding suggestions to improve their classroom learning effect.

(1)Clear their own learning goals, correct learning attitude. Adverse feelings never depend on your own state of mind. And more students and teachers to communicate, to find a suitable listener to talk to their own inner thoughts and actively into the new environment. Try to fall in love with your own school and profession, keep an optimistic attitude and embrace everything to meet any challenge

(2) Students should pay attention to the interaction with other students in class. When the teacher asked everyone to discuss the problem, the highly qualified students to actively participate in, rather than their own closed. When the teacher and other students to discuss the problem, the other students should also be active to listen, do not ignore this, so that a single interaction will become a whole interaction, will be very helpful to improve the classroom learning effect of college students.

\section{REFERENCES}

[1] T.F.GUO, Y.H.TIAN. The influence mechanism of knowledge workers' high knowledge on their knowledge sharing and emotional commitment [J]. Soft Science, 2015,29 (3): 88 92 
[2] Freeman RB. The over educated American[M]. New York: Academic Press, 1996.34 41

[3] Johnson. Perceived over qualification and psychological well-being. Journal of Social Psychology[J]. 1996, 136(24): 435 445

[4] Maynard D.C. Underemployment, job attitudes, and turnover intentions. Journal of Organizational Behavior[J].2006, 27(12), 509 536

[5] X.H.Chen, L.Cui. Cultivating College Students' Interests and Improving the Quality of Undergraduate Teaching [J]. Education Exploration. 201 6, (3): $45 \sim 48$

[6] Jennifer Fredrick. School Engagement: Potential of the Concept, State of the Evidence[J]. Review of Educational Research, 2004, 74(01): 60 62

[7] Dixon N.M.Common Knowledge:How Companies Thrive on Shar ing What They Know[M]. New York:Harvard University Press, 2015. 30 32

[8] Bartol KM, Srivastava A. Encouraging Knowledge Sharing: The Role of Organizational Reward Systems [J]. Journal of Leadership \& Organizational Studies, 2012, 47 (1): $64 \sim 76$

[9] Z.Z, Z.X.CHEN. College students' coping performance relationship between learning burnout and learning input [J]. Chinese Journal of Health Psychology, 2014,5 (9): 706 708

[10] C.Z. Knowledge sharing of knowledge - based enterprises and its influencing factors $[\mathrm{J}]$. Journal of Shanghai Business College, 2016,42 (6): $6 \sim 7$ 